\title{
Dinâmicas profissionais contemporâneas: algumas contribuições da sociologia de Richard Sennett ${ }^{\star}$
}

\author{
Carolina Salomão Corrêa, ${ }^{\star \star}$ Solange Jobim e Souza ${ }^{\star \star \star}$ \\ Pontificia Universidade Católica do Rio de Janeiro, Rio de Janeiro, RJ, Brasil
}

\section{Resumo}

Richard Sennett é um interlocutor fundamental para quem deseja analisar as reconfigurações das condições do trabalho contemporâneo. Como analista social, Sennett sempre contemplou em suas investigações as influências das transformações sócioeconômicas no âmbito das dinâmicas de trabalho. Este artigo teve como objetivo principal propor um diálogo entre a sociologia de Richard Sennett e relatos de jovens profissionais sobre suas dinâmicas de trabalho. Para tecer esse diálogo, as noções de flexibilidade, perícia e colaboração - fundamentais na obra do autor - foram confrontadas com a fala dos entrevistados, observando consonâncias e divergências. Os depoimentos trouxeram duas grandes contribuições para a reflexão sobre o tema: evidenciaram como a estrutura da empresa molda práticas profissionais individuais; e demonstraram as diferentes compreensões dos conceitos em contextos laborais distintos. Nesse sentido, a interlocução entre literatura e depoimentos evidenciou que esses conceitos não podem ser interpretados a priori, uma vez que seus significados e valores são construídos no ambiente das organizações.

Palavras-chaves: trabalho; colaboração; flexibilidade e perícia.

\section{Contemporary professional dynamics: contributions of Richard Sennett's sociology}

\begin{abstract}
Richard Sennett is a key interlocutor for those who want to talk about contemporary work. As a social analyst, Sennett has always contemplated in his investigations the influences of socio-economic transformations in the context of work dynamics. The main goal of this article was to propose a dialogue between Richard Sennett's sociology and the stories of young professionals about their work dynamics. In order to weave this dialogue, the notions of flexibility, expertise and collaboration - key in the author's work - were confronted with the interviewees' speech, noting consonances and divergences. The interviews brought two major contributions to the debate on the topic: they showed how the company's structure shapes individual professional practices; and demonstrated the different understandings of the concepts in distinct work contexts. In this sense, the dialogue between literature and interviews pointed out that these concepts can't be interpreted a priori, since their meanings and values are built in the organizations' environment.
\end{abstract}

Keywords: work; collaboration; flexibility and expertise.

\section{Introdução}

Richard Sennett, professor da New York University, da London School of Economics e da Cambridge University, em entrevista sobre o seu recente projeto Homo Faber, declarou seu desejo em buscar soluções, ao invés de apenas apontar os problemas. "É deprimente escrever somente sobre o que não funciona bem" (SENNETT, 2012b).

De fato, Sennet, motivado pelo apogeu do modelo neoliberal na virada da década de 1990, se ocupou em denunciar os perigos do que nomeou novo capitalismo. Nesse período, o autor escreveu uma série de ensaios críticos, expondo sua visão negativa em relação às conseqüências da lógica capitalista nos diferentes aspectos da vida humana. Seu trabalho mais marcante dessa época é, sem dúvida, A corrosão do caráter (SENNETT, 1999). Esta obra, que foi eleita pela revista Business Week o melhor livro de 1998, se debruça sobre as conseqüências pessoais do capitalismo no trabalho e na vida das pessoas. Sennett defende a tese de que

$\star$ Apoio: CNPq, FAPERJ e CAPES

$\star \star$ Endereço para correspondência: Pontifícia Universidade Católica do Rio de Janeiro, Centro de Teologia e Ciências Humanas, Departamento de Psicologia. Rua Marquês de São Vicente, 225 - Gávea. Rio de Janeiro, RJ - Brasil. CEP 22543900.E-mail: carolina salomao@yahoo.com.br, soljobim@puc-rio.b

$\star \star \star$ Pesquisadora do CNPq, FAPERJ e CAPES (Estágio Sênior na Université Vincennes Saint Dennis - Paris VIII). o imperativo da flexibilidade imposto por uma nova configuração econômica - o "novo capitalismo" - é nocivo ao caráter pessoal. O lema "não há mais longo prazo" da nova economia coloca em xeque as noções de compromisso, confiança e lealdade. O autor argumenta que os valores anteriormente citados só podem ser construídos e fundamentados através de "laços fortes que dependem da associação a longo prazo" (SENNETT, 1999, p. 25). Nas publicações posteriores, Respeito e A cultura do novo capitalismo, Sennett (2004, 2006) reitera sua crítica à nova configuração do capitalismo e os impactos dessas mudanças nos nossos valores sociais e culturais. Opondo o novo ao velho, Sennett soa saudoso na comparação entre o capitalismo industrial do século XIX e o novo capitalismo global do século XX. Embora, reconheça os aspectos opressivos do modelo de produção "militarizado" das indústrias, Sennett argumenta que as rígidas estruturas burocráticas e o tempo rotinizado permitiam a construção de uma narrativa pessoal, ao passo que a fluidez das instituições contemporâneas deixa os indivíduos à deriva, para usar expressão do próprio autor. É, portanto, com pessimismo que Sennett vê as transformações que retrata. 
No entanto, o autor reconhece que o momento é de nova transformação. $\mathrm{O}$ modelo neoliberal que o motivou a escrever os ensaios críticos entrou em crise, no que diz respeito à sua manutenção financeira e a sustentabilidade de suas fontes. O autor pondera: "hoje, eu diria que a ideia de encontrar uma alternativa não é um projeto utópico, mas algo que precisamos fazer porque esse sistema não funciona" (SENNETT, 2012b, online).

Buscar soluções é a proposta do novo projeto de Sennett. A trilogia Homo Faber tem como temática central o que $\mathrm{o}$ autor considera as habilidades fundamentais para a condução da vida cotidiana. $\mathrm{O}$ título do projeto referese às reflexões propostas por Hannah Arendt (1958), em A condição humana. Nesta obra a autora sistematiza a condição humana entre labor, trabalho e ação, além de sugerir uma dicotomia entre trabalho manual (homem que faz) e intelectual (homem que pensa). Sua intenção é mostrar as limitações do pensamento marxista ao limitar trabalho à atividade produtiva. Em Homo Faber, Sennett recusa essa divisão e desenvolve suas argumentações nos três livros que compõem o projeto. Em $O$ artifice, Sennett (2009) estabelece um vínculo entre o fazer e o pensar, articulando a relação entre o trabalho manual e mental. $\mathrm{Na}$ tese do autor, é tão artífice um carpinteiro quanto um programador de software, uma vez que para ambos os ofícios são necessários maestria técnica, colaboração e experimentação, além de uma compreensão mental daquilo que se produz. Em Juntos, Sennett (2012a) dá continuidade às reflexões iniciadas em $O$ artífice, explorando a idéia de cooperação como uma habilidade fundamental na realização de tarefas práticas. Dividido em três partes, Juntos explora de que maneira a cooperação pode ser moldada, debilitada ou fortalecida nas relações sociais e profissionais. No terceiro livro, ainda em desenvolvimento, o autor buscará aplicar as reflexões dos dois primeiros livros numa reflexão sobre urbanismo e arquitetura. Sennett acredita que as cidades podem ser melhores do que são na atualidade. A trilogia Homo Faber, é, portanto, um projeto propositivo que busca destacar aspectos mais positivos do trabalho. Por longo tempo, o autor dedicou-se a expor os problemas do trabalho no capitalismo moderno, em geral de forma bastante crítica em relação à maneira como as pessoas trabalham. No novo projeto, Sennett indica o que considera uma boa maneira de trabalhar.

Assim, este artigo percorre esses dois momentos da bibliografia de Sennett buscando identificar consonâncias e divergências das argumentações do autor com realidades profissionais específicas. Para tanto, as reflexões bibliográficas são postas em diálogo com depoimentos de jovens profissionais de diferentes esferas produtivas.

Ao longo de dois meses, essa pesquisa se propôs a conversar com alguns jovens sobre os seus trabalhos. De modo mais específico, o objetivo foi conhecer as práticas profissionais, o cotidiano e as percepções sobre o ambiente onde, os jovens entrevistados nesta pesquisa, passam grande parte do seu tempo diário. Para tanto,

Fractal, Rev. Psicol., v. 29 - n. 1, p. 54-64, 2017 foram formuladas algumas questões ${ }^{1}$ que permitiram iniciar uma narrativa a respeito do tema. Para essa etapa da pesquisa, optou-se por conversas quase sempre ocasionais, favorecidas pela proximidade e convivência estreita com as pessoas. No entanto, dois critérios foram adotados na escolha dos interlocutores: ter ensino superior e estar inserido no mercado de trabalho há, pelo menos, cinco anos. Tendo em vista os critérios assinalados, a pesquisa foi realizada com 11 jovens, na faixa etária entre 26 e 33 anos. A identidade dos entrevistados foi preservada através de nomes fictícios; ${ }^{2}$ do mesmo modo, as empresas onde eles trabalham não foram nomeadas. Contudo, vale assinalar que é possível compreender, no contexto da narrativa desenvolvida no âmbito da entrevista, a atividade desempenhada por eles e suas áreas de atuação.

Estabelecer um diálogo sobre o assunto foi também uma tentativa de fugir ao reducionismo econômico que a idéia de um caráter formado pelo capitalismo pode evocar. Foucault (1996) afirma que uma sociedade não é definida pelo seu modo de produção, mas pelo seu regime discursivo, pelos enunciados que ela formula e pelas visibilidades que tais enunciados efetuam. Nesse sentido, as falas destacadas pretendem ilustrar os conceitos, valores e experiências que os entrevistados destacaram, permitindo dar maior visibilidade às condições e às dinâmicas de trabalho a que estão sujeitos.

Como já dito, nesse artigo, os depoimentos objetivam amparar uma reflexão a partir da produção intelectual de Richard Sennett. As noções de flexibilidade, maestria, competição e colaboração, discutidas pelo autor, são colocadas em diálogo com os depoimentos dos entrevistados.

\section{Contribuições para investigações em subjetividade e trabalho \\ No meu outono, tornei-me mais esperançoso quanto o animal humano no trabalho [...] podemos alcançar uma vida material mais humana, se pelo menos entendermos como são feitas as coisas (SENNETT, 2009, p. 18).}

Como analista social, Sennett sempre contemplou em suas investigações as influências das transformações sócio-econômicas no âmbito das dinâmicas de trabalho. Embora $A$ corrosão do caráter (SENNETT, 1999) seja um marco da produção do autor sobre o assunto, seu trabalho inaugural sobre as implicações da nova economia na esfera do trabalho remete a 1972, quando em coautoria com Jonathan Cobb, Sennett escreveu The hidden injuries of class, um ensaio sobre a realidade de operários norte-americanos. A hipótese dos autores é de que a

\footnotetext{
As perguntas elaboradas para a entrevista não seguiram um roteiro rígido e sistemático. A entrevista teve como base questões iniciais feitas pela pesquisadora, de modo simples e direto. A intenção era permitir que o(a) entrevistado(a) escolhesse o encaminhamento do assunto de acordo com sua experiência de trabalho. Podemos citar, a título de exemplo, algumas perguntas: onde você trabalha? Quais as atividades que você desenvolve no seu trabalho? Alguém trabalha com você nessa atividade (há uma equipe)? Para você o que é um bom dia de trabalho? A partir desta abordagem inicial novas perguntas eram geradas com base nos temas que foram sendo construídos ao longo da entrevista. Em síntese, a partir do tema das dinâmicas de trabalho no mundo contemporâneo, e tendo como referência teórica as ideias de Sennet, o diálogo com os jovens entrevistados foi sendo elaborado. Posteriormente procedemos à análise do material discursivo, levando em conta as possibilidades discursivas na cena específica em que as indagações ocorreram.

${ }^{2} \mathrm{~A}$ opção pelo anonimato foi acordada entre a pesquisadora e entrevistados.
} 
própria dignidade humana é ameaçada quando se adota uma divisão arbitrária de valores e talentos representada pela estrutura de classes. Nesse livro, os autores focam nos impactos emocionais, mais do que econômicos da organização por hierarquia na sociedade norte-americana. Esse tipo de abordagem é o que distingue a sociologia de Richard Sennett. Para desenvolver suas reflexões, o autor utiliza dados econômicos e teorias sociais, mas recorre com muita freqüência a narrativas pessoais e à vida diária dos sujeitos. Em Respeito (SENNETT, 2004) o autor lida com questões como auto-estima e compaixão em um universo de desigualdades; em A cultura do novo capitalismo, Sennett (2006) destaca os mal-estares causados pelas incertezas de um universo profissional cambiante. Em $A$ corrosão do caráter (SENNETT, 1999) é a ameaça aos conceitos de lealdade, confiança e comprometimento que preocupa o autor. Essa ênfase nas implicações subjetivas das mudanças faz da bibliografia de Richard Sennett uma rica contribuição para os estudos da produção da subjetividade no universo profissional contemporâneo.

Observa-se que tanto nas publicações iniciais quanto nas produções mais recentes, o foco do autor pode ser resumido por uma busca de compreensão acerca dos sentidos que são construídos pelos sujeitos - individualmente - e pela sociedade, em contextos sócio-econômicos críticos. Na virada do século, o "novo capitalismo" alterou a rotina e a ética do trabalho. As relações de curto prazo, típicas dessa nova cultura, colocaram em risco o progresso coletivo. Hoje, o panorama não é mais animador; segundo o autor continuamos em condições econômicas e sociais desfavoráveis. No entanto, Sennett persiste em ser mais esperançoso.

Assim, ainda que o projeto Homo Faber marque um novo momento no trabalho do autor, vale ressaltar que não se trata tanto de uma mudança de pensamento e sim de postura. Sennett permanece insatisfeito com o rumo das coisas, no entanto, ele acredita que trabalhando juntos, detectando e resolvendo problemas à maneira do artífice, podemos ampliar nossa capacidade de redesenhar o cenário.

Embora essa breve contextualização teórica tenha se orientado por um paradigma temporal, esse artigo não percorre um caminho cronológico da obra do autor. São os temas que criam a narrativa, fazendo pontes entre obras passadas e atuais. Ao longo de sua bibliografia, Sennett constantemente revisita tópicos essenciais, como autoridade, colaboração, flexibilidade e autonomia, enriquecendo suas análises com novos exemplos e aportes teóricos. Esse trabalho busca traçar um paralelo entre a realidade apresentada por Sennett nas suas publicações e as experiências narradas pelos entrevistados; identificando pontos de convergências e dissonâncias.

\section{Flexibilidade: liberdade ou armadilha?}

A sociedade hoje busca meios de destruir os males da rotina com a criação de instituições mais flexíveis. As práticas de flexibilidade, porém, concentram-se nas forças que dobram as pessoas (SENNETT, 1999, p. 53).
Em seus ensaios críticos da virada do século, Sennett alerta: as novas maneiras de organizar o tempo, típicas do novo capitalismo, são nocivas e desestruturantes. Para autor o ambiente de trabalho moderno, com ênfase nos trabalhos a curto prazo, na execução de projetos e na flexibilidade, não permite que as pessoas desenvolvam experiências e construam uma narrativa coerente para suas vidas. Para ilustrar sua argumentação, no capítulo inicial de A corrosão do caráter, Sennett (1999) relata um encontro com Rico, um jovem angustiado com o descontrole de sua vida pessoal e profissional. Rico é filho de Enrico, trabalhador, imigrante italiano, que Sennett havia entrevistado 20 anos antes, quando escreveu The hidden injuries of class. Na época, Enrico trabalhava como faxineiro e economizava para garantir ensino superior aos seus filhos. Ao encontrar Rico no saguão de um aeroporto, Sennett constata que Enrico foi bemsucedido no projeto, mas o relato não é feliz. A partir da oposição das trajetórias de pai e filho, Sennett busca demonstrar os impactos das mutações no universo de trabalho na vida emocional de Rico. O autor explica que enquanto Enrico vivia numa realidade marcada por uma ordem racionalista e estruturas burocráticas rígidas - a "jaula de ferro" de Max Weber - que lhe permitia criar uma narrativa para sua vida, Rico, seu filho, "vive num mundo caracterizado, ao contrário, pela flexibilidade e o fluxo a curto prazo; esse mundo não oferece muita coisa, econômica e socialmente, para a narrativa" (SENNETT, 1999 , p. 32). Sennett (1999, p. 49) defende que "enjaulado", Enrico foi capaz de planejar e concretizar suas metas, isso porque "a rotina pode degradar, mas também proteger; pode decompor o trabalho, mas também compor uma vida". As circunstâncias sócioeconômicas sempre cambiantes lançaram Rico de um emprego a outro. Constantemente obrigado a mudar de cidade, Rico lamenta a falta de laços comunitários e o alheamento em relação à educação de seus filhos. A angústia de Rico deriva, portanto, das condições do tempo no novo capitalismo.

A comparação entre as biografias de pai e filho ilustra a hipótese do autor de que embora a "jaula de ferro" weberiana tenha se quebrado, não estamos mais livres do que quando enjaulados. Eis a argumentação do autor:

Diz-se que, atacando a burocracia rígida e enfatizando o risco, a flexibilidade dá às pessoas mais liberdade para moldar suas vidas. Na verdade, a nova ordem impõe novos controles, em vez de simplesmente abolir as regras do passado - mas também esses novos controles são difíceis de entender. O novo capitalismo é um sistema de poder muitas vezes ilegível (SENNETT, 1999, p. 10).

Para o autor, passamos de um controle a outro, do medo do fracasso à ansiedade das incertezas. No entanto, embora Sennett acene com os efeitos nocivos e ilusórios da flexibilidade, nos depoimentos, flexível foi um atributo desejado em oposição a estruturas burocráticas engessadas. Nesse ponto, é preciso compreender o que está sendo entendido por flexibilidade nas falas dos entrevistados. 
Motivada pela descrição de Sennett de seu encontro com Rico, numa manhã de novembro, encontrei Cláudia para um café e uma conversa sobre seu trabalho. ${ }^{3}$ Embora sejamos amigas há algum tempo, nunca havíamos sentado para conversar especificamente sobre o assunto. Formada em desenho industrial, Cláudia já havia trabalhado autonomamente com assessoria de imprensa, consultoria e produção de moda. Há dois anos trabalha como assistente de edição numa editora de médio porte. Embora muito mais identificada com o trabalho atual, Cláudia lamenta a falta de liberdade imposta pela estrutura organizacional da nova empresa. Acostumada com flexibilidade de tempo e espaço que os trabalhos autônomos permitiam, Claúdia lamenta a rigidez da editora.

Ela explicou que como assistente de edição, suas atividades diárias consistem em fazer avaliações de originais, emitir pareceres, além de fazer produção editorial de títulos já comprados pela editora. Internet e computador são os únicos recursos que ela reconhece como fundamentais para a realização do seu trabalho diário. Sendo assim, ela acredita que poderia desempenhar suas funções de casa. No entanto, a editora não adota a prática de home office.

Eu tenho muita dificuldade de ficar presa a um lugar e um horário; a gente tem um cartão de ponto, e isso é uma coisa que me angustia, mesmo porque eu tenho um histórico de trabalho anterior que era muito mais livre, mais solto, de poder ir para rua e ver o dia. E eu acho, pensando em dinâmicas de editora em geral, que é um trabalho que eu não precisaria ir ao escritório todo dia, sabe? Eu tenho certeza, é um trabalho que eu tô lendo o dia inteiro. Eu poderia fazer isso em casa. E não tem essa política. Eu gostaria que tivesse, talvez não todos os dias, mas acho que é uma possibilidade, dentro do mundo de editora é muito possivel porque em termos de material para trabalhar, eu preciso de um computador, internet e só. Mas essa flexibilidade não existe lá (Claúdia).

A inflexibilidade da empresa no que se refere a horários e folgas também a aborrece. Para Cláudia falta um investimento numa estrutura física, mas também numa estrutura emocional.

Eu poderia te dar mil exemplos e você poderia pensar "ah que bobagem, coisa mimada", tipo agora, semana que vem, tem um feriado quinta e um feriado terça, a gente vai trabalhar sexta e vai trabalhar segunda, a gente trabalha quarta-feira de cinzas, a gente trabalha 24 de dezembro. $\dot{E}$ para aborrecer. [...] então eu acho que falta investimento numa estrutura fisica, mas falta investimento numa estrutura emocional, entre aspas, sabe? Mas eu acho que isso nunca vai ter porque o dono não está aberto a isso. A gente vê isso no dia a dia (Claúdia).

A esse tempo flexível reivindicado por Cláudia, Sennett nomeou "flexitempo". O autor destaca que horários flexíveis são um falso privilégio uma vez que promete maior liberdade, mas envolve numa nova trama de controle. Em muitos depoimentos, a

\footnotetext{
${ }^{3}$ Trechos narrados em primeira pessoa foram retirados do diário de bordo da pesquisadora Carolina Salomão Corrêa e refletem a dinâmica do encontro entre pesquisadora e entrevistado. As entrevistas foram gravadas e posteriormente transcritas.
}

possibilidade de trabalhar de casa, apareceu como uma recompensa por uma confiança adquirida ou por uma garantia de produção igual ou até superior a do escritório, ainda que remotamente. Sennett lembra, no entanto, que essa recompensa causa grande ansiedade entre os empregadores, temendo perder o controle sobre os empregados, as empresas desenvolvem novos mecanismos de vigilância.

Em consequência criou-se um monte de controles para regular os processos de trabalho concreto dos ausentes do escritório. Exige-se que as pessoas telefonem regularmente para o escritório, ou usam-se controles de intrarrede para monitorar o trabalhador ausente; os e-mails são frequentemente abertos pelos supervisores. Poucas organizações que montam esquemas de flexitempo dizem a seus trabalhadores: "aqui está sua tarefa, faça como quiser contanto que seja feita" [...] Um trabalhador em flexitempo controla o local do trabalho, mas não adquire maior controle sobre o processo de trabalho em si. Vários estudos sugerem que a supervisão do trabalho muitas vezes é na verdade maior para os ausentes do escritório que para os presentes (SENNETT, 1999, p. 68).

O autor adverte ainda que se o flexitempo é recompensa para o empregado, também o põe no domínio íntimo da instituição. Ocorre que com a possibilidade de trabalho remoto viabilizada pelas tecnologias de comunicação, tempo de trabalho e tempo de não trabalho constantemente se misturam. A facilidade de acesso fornece a falsa idéia de disponibilidade irrestrita.

Cecília estava chegando de São Paulo quando a recebi em casa para uma pizza e um bate-papo. Passava das $21 \mathrm{~h}$, e ela retornava de compromisso de trabalho na cidade. Gerente há três anos numa empresa de comunicação e entretenimento, com escritório no Rio de Janeiro e Los Angeles, viagens são freqüentes em sua rotina. Aproveitando o gancho do horário, quis entender como o tempo de trabalho é estabelecido na empresa.

[...] a gente não tem uma cultura definida, porque tem empresa que já estabelece, né? "Você chega a hora que você quer e você sai a hora que você quer, é assim, é só entregar". Acho que para uma empresa ter isso, ela precisa ter o mínimo de estrutura com outras coisas, sabe? Como, por exemplo, você saber exatamente qual o seu papel na empresa e sua entrega, é com isso que você tem que se preocupar; assim fica mais fácil dar uma liberdade maior para as pessoas. [...] mas de certa forma você tá trabalhando, você tem uma entrega para um cliente, você fica até duas horas da manhã, é dificil que seja esperado que você esteja no dia seguinte, no escritório, às $9 h$, né? (Cecília).

É possível perceber no depoimento de Cecília, que a falta de estrutura faz com que os acordos de tempo se estabeleçam tacitamente. Como na narrativa de Rico, existe pouca previsibilidade em relação às condições de trabalho. Seu horário é montado a partir de demandas do momento. Deste modo, as possibilidades de liberdade e autonomia ficam condicionadas a realidades sempre provisórias. Sennett (2006, p. 52) explica que em ambientes como o descrito por Cecília, é preciso ter 
um "alto grau de tolerância com a ambiguidade". Nas estruturas burocráticas, os empregados podiam contar com uma cadeia de comando que estabelecia exatamente a função que deveria ser desempenhada; nesse sentido, paradoxalmente, o trabalhador poderia criar e se organizar dentro desse universo, ainda que limitado. Em contrapartida, nas organizações flexíveis, "a estrutura não constitui um sólido objeto passível de estudo, seu futuro não pode ser previsto", em empresas onde as estruturas não são suficientemente claras é preciso próatividade diante de situações ambíguas, nesses ambientes a sensibilidade substitui o dever.

$\mathrm{O}$ autor alerta que esse novo modo de operar gera graves déficits sociais, tais como: baixo nível de lealdade, diminuição da confiança e enfraquecimento de um conhecimento institucional. Esses déficits dizem respeito à redução do valor do capital social. $\mathrm{O}$ autor explica que "o capital social é baixo quando as pessoas consideram que seu envolvimento é de baixa qualidade, e alto quando acreditam que seus vínculos são de boa qualidade" (SENNETT, 2006, p. 62). Conforme narrado por Cecília é difícil trabalhar com liberdade e de forma autônoma quando não se sabe exatamente o que é esperado de você.

Desestruturados, os indivíduos ficam entregues a si mesmo, podendo recorrer apenas à sua própria capacidade para melhor reagir às ordens, objetivos e avaliações de desempenho que partem do centro. [...] Com isto, a empresa não precisa mais pensar de maneira crítica sobre sua responsabilidade em relação àqueles que controla (SENNETT, 2006, p. 60).

Assim, para o autor, o fim da burocracia e a flexibilidade "trai o desejo pessoal por liberdade [...] $\mathrm{Na}$ revolta contra a rotina, a aparência de nova liberdade é enganosa" (SENNETT, 1999, p. 69). Sennett (2006) destaca ainda que a crescente "casualização" da força de trabalho - próprias das organizações flexíveis - conduziu a uma intensificação do trabalho e a precarização das relações trabalhistas. $O$ autor justifica a afirmação argumentando que a opção por contratação por trabalhos temporários permite que os empregadores se eximam de pagar benefícios que seriam próprios aos trabalhadores, como pensões e seguro de saúde. "Além disso, os trabalhadores vinculados por contratos de curta duração podem ser facilmente transferidos de uma tarefa a outra" (SENNETT, 2006, p. 50). A estrutura flexível serve à empresa que, para atender as demandas volúveis, pode contrair-se ou expandir-se rapidamente. Para tanto a relação com o trabalho se estabelece em vínculos precários - hora extra, trabalho temporário, subcontratação.

Há cinco anos trabalhando numa empresa multinacional de consultoria na área de tecnologia da informação, Laura trocou o trabalho autônomo numa agência de publicidade pela segurança de um trabalho de carteira assinada na iniciativa privada. Para ela, os ganhos em liberdade não compensam a insegurança desse tipo de estrutura. A falta de direitos e as incertezas em relação ao salário e à própria garantia do emprego motivaram a mudança.
Eu trabalhava como PJ (pessoa jurídica), tinha que emitir nota fiscal, não tinha direito a nada, se tivesse uma doença eu não recebia, se eu ficasse doente e faltasse eu não ia receber, não tinha direito a nada, férias, $13^{\circ}$ salário, então eu tava atrás de carteira assinada. Uma estabilidade entre aspas, que não é a mesma de um emprego público, mas é de uma empresa que te reconhece, que te dá um plano de saúde, um plano odontológico, que dá um seguro desemprego se você for demitida, FGTS, esse tipo de coisa, e eu estava atrás disso porque estava querendo casar, engravidar e queria a segurança de ficar com o meu filho quatro meses em casa (Laura).

O depoimento de Laura corrobora a hipótese de Sennett de que o fim da "jaula de ferro" não representou necessariamente conquista de liberdade. Assim como Rico, para traçar uma narrativa em relação ao seu futuro (casamento e gravidez) Laura recorreu a uma estrutura mais rígida que a permitisse planejar sua vida. Sennett lembra que no capitalismo social militarizado "tornou-se possível definir como seriam as etapas de uma carreira, relacionar um longo percurso de prestação de serviços numa empresa a passos específicos de acumulação de riqueza" (SENNETT, 2006, p. 29). Embora, a empresa de Laura esteja longe do modelo militarizado, aspectos mais tradicionais de sua estrutura garantem aos seus empregados um senso de pertencimento e segurança que o trabalho autônomo nega. Sennett (2006, p. 75) explica, com base nas suas pesquisas, que após alguns anos em trabalhos temporários, as pessoas tendem a considerar "mais importante participar de uma estrutura social do que dispor de mobilidade pessoal".

Entretanto, embora flexibilidade seja comumente atrelada à idéia de precarização - representada em perda de direitos trabalhistas, enfraquecimento das organizações sindicais, intensificação do trabalho - é possível encontrar interpretações que a desloque de uma condição meramente negativa. $\mathrm{O}$ próprio autor desenvolve argumentações onde a flexibilidade é bemvinda. Em Juntos (SENNETT, 2012a), o autor explica que a colaboração no reino animal é antes de tudo um imperativo de sobrevivência. "Todos os animais sociais colaboram porque na solidão a abelha, o lobo ou o ser humano não são capazes de garantir a própria sobrevivência" (SENNETT, 2012a, p. 90). Sennett pega emprestado conceitos da etologia para explicar que embora a cooperação seja uma condição vital para os seres, ela não acontece de forma simplesmente instintiva ou estática. Embora esteja inscrita em nossos genes, os estados de cooperação são instáveis, porque o ambiente natural não é fixo. Diante das mutabilidades é preciso uma organização flexível que dê conta das imprevisibilidades. As divisões de trabalho são o recurso adotado pela maioria das espécies para compensar nossa incompletude de competências. No entanto, essas divisões não podem ser rígidas, Sennett recorre ao exemplo das colméias e formigueiros para clarificar a afirmação. Nessas comunidades, em casos de crise, falta ou infortúnios, formigas e abelhas contam com um código genético que permitem que eles troquem de função e assumam 
tarefas temporárias para garantir o equilíbrio do sistema. "No formigueiro ou na colméia rigidez e eficiência não combinam; a cooperação é mais flexível” (SENNETT, 2012a, p. 90). O exemplo, tirado da biologia, parece distante da realidade do universo do trabalho humano. Sennett discorda, em ambientes onde não é possível garantir estabilidade, a flexibilidade é imprescindível.

Diante de considerações tão díspares é possível concluir que as mutações ocorridas no âmbito do trabalho no que se refere à flexibilização têm gerado mais dissenso que consenso. Flexibilidade é, portanto, conceito que pede recorrência a diversas unidades de análise, buscando conhecer as especificidades de cada contexto.

\section{"Não há mais longo prazo" e a desvalorização da perícia}

Outro aspecto negativo do novo capitalismo amplamente discutido por Sennett refere-se ao declínio das relações pessoais e profissionais de longo prazo. Para o autor as novas maneiras de organizar o tempo são as características distintivas do capitalismo da nossa época.

É a dimensão do tempo do novo capitalismo, e não a transmissão de dados high-tech, os mercados de ação globais ou o livre comércio, que mais diretamente afeta a vida emocional das pessoas fora do local de trabalho. Transposto para a área familiar, "Não há longo prazo" significa mudar, não se comprometer e não se sacrificar (SENNETT, 1999, p. 25).

Sennett destaca que o lema "não há longo prazo" implica em duas grandes conseqüências (intimamente relacionadas) para o universo do trabalho. A primeira diz respeito aos prejuízos no campo da organização do tempo e na construção de sentido através de narrativa lineares. $O$ autor destaca que a adoção crescente de vínculos por contrato, atendendo demandas específicas e, portanto episódicas colocou em xeque a noção tradicional de carreira, deixando os trabalhadores à deriva no que diz respeito ao planejamento de um futuro pessoal e profissional. Além disso, modelos de relacionamento a curto prazo enfraquecem laços sociais importantes nas esferas subjetivas do relacionamento. Como dito anteriormente, vínculos de confiança, lealdade e autonomia precisam de tempo e estruturas sólidas para serem desenvolvidos. Esse novo modelo nega a possibilidade de construção desses laços a partir de relações sempre pontuais e intermitentes.

O outro aspecto refere-se ao declínio da perícia como um valor no universo profissional atual. Sennett explica que as dinâmicas de trabalho no regime flexível levaram à extinção da capacitação e desvalorização da experiência. O sujeito inserido na lógica flexível e cambiante da nova economia se vê impelido a enfrentar diversos desafios para adaptar-se e, em termos mais dramáticos, sobreviver. Um desses desafios refere-se a lidar com a desvalorização da sua capacidade e o jugo do tempo. Sennett ressalta que a perícia, ou seja, a capacidade de fazermos algo com maestria não encontra espaço nas instituições do capitalismo flexível. E isso, para algumas pessoas, é conflitante. O autor explica:

Quanto mais sabemos como fazer alguma coisa bem- feita, mais nos preocupamos com ela. Todavia, as instituições baseadas em relações de curto prazo e tarefas que estão constantemente sendo alteradas não propiciam esse aprofundamento. Na realidade, a organização pode mesmo temê-lo; [...] uma pessoa que mergulha fundo em determinada atividade simplesmente para fazer bem-feito pode parecer aos outros que está travada, no sentido que está fixada naquela coisa (SENNETT, 2006, p. 100).

Em $O$ artifice, Sennett (2009) recupera e aprofunda a questão da perícia. Enquanto nas publicações anteriores - A corrosão do caráter e $A$ cultura do novo capitalismo (SENNETT, 1999, 2006) - o autor analisa especificamente as relações de trabalho circunscritas nos espaços laborais, em $O$ artífice, Sennett (2009, p. 319) recorre à história, à biologia e à fisiologia, para demonstrar que o trabalho humano "pode ser enriquecido pelas capacitações e dignificado pela perícia artesanal”.

$\mathrm{Na}$ obra, o autor resgata valores iluministas que pregavam "que todo mundo tem a capacidade de fazer bem algum trabalho, que existe um artífice inteligente na maioria de nós" (SENNETT, 2009, p. 21), no entanto, essa habilidade não é honrada como deveria ser. O autor explica a habilidade do artífice.

Habilidade artesanal designa um impulso humano básico e permanente, o desejo de um trabalho bem feito por si mesmo. Abrange um espectro muito mais amplo que o trabalho derivado de habilidades manuais; diz respeito ao programa de computador, ao médico e ao artista; os cuidados paternos podem melhorar quando são praticados como uma atividade bem capacitada, assim como a cidadania. [...] As condições sociais e econômicas, contudo, muitas vezes se interpõem no caminho da disciplina e do empenho do artesão: é possível que as escolas não proporcionem as ferramentas necessárias para o bom trabalho e que nos locais de trabalho não seja realmente valorizada a aspiração de qualidade (SENNETT, 2009, p. 19).

Esses aspectos parecem particularmente verdadeiros no depoimento de Pedro e Leila. Ambos são economistas numa empresa pública de distribuição de energia. Embora gostem do que fazem, narram com frustração suas atividades diárias. Leila se sente subutilizada em seus conhecimentos, Pedro não se sente ouvido pelos seus superiores.

eu gosto de ficar ocupado, eu gosto quando tem um trabalho que eu possa pensar, entendeu? Mas o chato é que, às vezes, você faz um trabalho que precisa pensar, e o chefe vem e diz: "mas não precisava disso tudo", entendeu? Esses dias eles fizeram uma projeção, mas eles erraram a tarifa, ai eu fui e calculei exatamente a tarifa, montei uma equação e calculei qual seria exatamente a tarifa correta a ser calculada, demorei o maior tempo, e na prática, o cara falou "é, pode fazer desse jeito, mas não vai dar muito diferença não" e no dia seguinte já até perdeu essa idéia de fazer a projeção, não vai nem mais fazer, entendeu, é legal quando você faz e a parada acontece, mas muitas vezes a gente faz e a parada não acontece (Pedro). 
Leila compartilha o sentimento de frustração de Pedro. A superficialidade do seu trabalho, que segundo ela está muito aquém da sua formação e a falta de exigência de seus superiores lhe dá a sensação de não estar contribuindo.

[...] acaba que a gente faz um serviço muito técnico ali, acho que rola uma subutilização do nosso conhecimento (...) nosso cargo é de analista, mas eu não me sinto analista, entendeu? Eu acho que a gente poderia contribuir mais, sabe? Ali todos fizeram faculdades boas, a maioria fez especialização, fez mestrado, o Pedro está no doutorado, pô, a gente poderia agregar muito mais (Leila).

Sennett observa que embora as organizações precisem de gente inteligente, o imperativo da velocidade não permite que os profissionais se aprofundem em atividades específicas apenas para fazê-la bem feito. $\mathrm{O}$ autor explica que um jovem recém-saído da universidade precisa de tempo para entender o que realmente tem utilidade nas matérias que estudou e de prática para aperfeiçoar a habilidade. Contudo, as instituições precisam de indivíduos que façam muitas coisas de improviso, nesse sentido, o esforço para conquistar a maestria numa função é visto como obsessão indesejada.

Assim como Leila e Pedro, Marcelo, designer gráfico numa empresa de assessoria de comunicação de grande porte, também sofre quando sua capacidade de criação é tolhida pelas pressões de prazo. No seu depoimento, as características do artífice aparecem com muita clareza. No entanto, sua capacidade de criar, inovar e realizar seu trabalho com maestria encontra empecilhos no tempo. Respondendo sobre o que seria um bom dia de trabalho, Marcelo relatou:

Eu particularmente, me sinto realizado quando eu olho para um trabalho e tenho orgulho, eu digo "legal, eu consegui fazer algo diferente, eu consegui inovar de alguma maneira". Seja num resultado estético, no aproveitamento de papel, na forma de entrega, entendeu? Quando eu consigo realizar alguma coisa diferente do habitual, porque eu sempre busco, né, porque os prazos e a prática, às vezes, te tolhe, porque você já sabe como aquele cliente funciona, já sabe as coisas que aquele cliente gosta, então quando você não tem muito tempo você faz o que vai resolver, entrego o que sei que vai resolver, vai funcionar, vai dar certo, e às vezes você se limita, você não ousa, não dá um passo a mais [...] mas, quando você tem a liberdade de fazer algo novo, para mim o dia bom é isso, quando você consegue sair realizado.

Sennett desenvolve a ideia do consultor como a figura que melhor se adapta as novas configurações organizacionais. Diferente dos "peritos", os consultores estão na empresa sem se estabelecerem, são convocados para solucionar questões pontuais, sem se aprofundarem. A consultoria é o modelo paradigmático do trabalho contemporâneo. Enquanto o perito, assim como o "artesão", se preocupa com a qualidade e recusa a superficialidade; o consultor, ao contrário, tem compromisso com a velocidade, e vínculos frágeis com as instituições e seus pares. Conforme já foi mencionado, a figura do consultor serve aos interesses flexíveis da empresa.
Confiando certas funções a terceiros em outras firmas ou outros lugares, o gerente pode livrar-se de certas camadas na organização. A organização incha e se contrai, empregados são atraídos ou descartados à medida que a empresa transita de uma tarefa a outra" (SENNETT, 2006, p. 50).

No entanto, alguns depoimentos destacaram vantagens na prática de contratações por projetos e demandas. Contrariando a ideia de Sennett, Cecília narra uma experiência onde a contratação por projeto aparece como uma opção mais criativa, que econômica. Ela acredita que esse tipo de contratação possibilita uma seleção mais especifica de pessoa para o trabalho. Como exemplo, ela cita um projeto que sua empresa desenvolveu há alguns anos para uma marca de sucos que desejava estender seu conteúdo para diferentes plataformas entre elas um livro.

[...] a gente faz uma escolha, não só por uma questão financeira, mas também criativa, é que isso faz muito sentido para o que a gente faz. No projeto do suco, por exemplo, a gente pegou o briefing com o cliente e a gente desenvolveu as premissas desse universo, os personagens e tal; na hora de sentar para escrever um livro que ia ser lançado em capitulos, a gente chamou uma roteirista que tinha experiência com literatura infanto-juvenil e que escrevia para televisão, então tinha experiência com narrativa seriada. A gente "brifou" ela para ela ajudar a gente a escrever essa história. Então ela não é uma contratada nossa full time, ela foi chamada para esse projeto, e para gente faz sentido isso, porque a gente acredita que a gente pode encontrar pessoas certas para determinados trabalhos e não ter as pessoas "in house" o tempo todo (Cecília).

Sennett (2006, p. 23) destaca que contratações episódicas como a citada por Cecília são uma característica da moderna estrutura institucional. Para o autor essa dinâmica é extremamente nociva, visto que contratações esporádicas e de curto prazo inviabilizam o desenvolvimento de valores como lealdade e confiança, além impossibilitar o trabalhador de se qualificar em uma atividade específica, uma vez que é lançado de uma atividade à outra, à disposição de demandas mutantes. Paradoxalmente, é a própria Cecília que exemplifica a denúncia do autor. Embora identifique aspectos positivos nas contratações por projetos, ao narrar sua trajetória na empresa, Cecília demonstra incômodo em não saber especificar sua atividade principal.

Como a empresa é muito pouco estruturada, e é uma coisa que me incomoda, de certa forma, mas eu não tenho uma função definida. E pela estrutura da empresa, eu acabo conseguindo navegar tanto pela área de estratégia, tanto pela área de conteúdo, o que pode parecer ótimo, mas na verdade não é, porque eu fico um pouco indefinida. Acabo que eu não me especializo em nada específico, sabe? Eu gostaria muito que fosse algo especifico, mas não é(Cecília).

Sennett (2006) parece entender o sofrimento narrado por Cecília. Para o autor, o ser humano para prosperar em condições sociais instáveis e fragmentárias precisa enfrentar alguns desafios. Um deles refere-se ao talento: "como desenvolver novas capacitações e descobrir capacidades potencias à medida que vão mudando às exigências da realidade" (SENNETT, 2006, p. 13). 
Uma individualidade voltada para o curto prazo, preocupada com habilidades potencias e disposta a abrir mão das experiências passadas só pode ser encontrada - para colocar as coisas em termos simpáticos - em seres humanos nada comuns. A maioria das pessoas não é assim, orgulhandose de sua capacitação em algo específico e valorizando as experiências por que passou. Desse modo, o ideal cultural necessário nas novas instituições faz mal a muitos dos que nela vivem (SENNETT, 2006, p. 15).

No entanto, mais uma vez o sentimento se mostra contraditório quando ouvimos o depoimento de Sofia. Sofia é professora de Artes numa faculdade, faz trabalhos freelancer como jornalista e integra um coletivo de arte, atividade que hoje ocupa maior parte de seu tempo. Ela me recebeu para um almoço em sua casa e se dispôs a me explicar suas diferentes práticas profissionais.

Sofia: [...] as pessoas têm uma dificuldade, hoje, no mundo, de entender isso [...] porque se você é uma coisa, você é uma coisa; mas você não é só uma coisa.

E: que coisa?

Sofia: tipo uma profissão, sou designer sei lá, não existe isso de ser só designer, em um coletivo, existe um monte de designer que é atriz, mesmo, que faz peça, mas que trabalha de designer para ganhar dinheiro. Enfim, a gente faz coisas para além do que a gente gostaria de ser só.

E: mas você gostaria de ser só uma coisa?

Sofia: sei lá, acho que eu não gostaria porque acho que isso nem é viável, sabe?

Para Sofia, a idéia de uma carreira única, vitalícia além de inviável, é aprisionante. Ela destaca que a possibilidade de desempenhar diferentes funções e atuar em múltiplos espaços lhe dá liberdade para escolher seus projetos, referenciada pelos seus desejos, e não por necessidades externas. Ela explica:

Eu sempre gostei de ter o meu dinheiro espalhado em vários lugares, porque aí você não se prende a lugar nenhum, sabe? Você fica sempre na borda; não quer? Beleza, vai fazer outra coisa então [...] eu não quero ficar presa a alguma coisa que é para além da minha vontade de estar ali, sabe? (Sofia).

À primeira vista, Sofia pode parecer aquele ser humano nada comum a que Sennett se referia, ser humano disposto a abrir mão de experiências pretéritas e indiferente a capacitações específicas. No entanto, essa interpretação é por demais simplista. Sofia valoriza relações pessoais, orgulha-se de suas experiências, mas como artista, encara a formação versátil como possibilidade de liberdade e aprendizado.

Bruno, marido de Sofia, faz parte de um outro coletivo que reúne atores, cineastas, filósofos, diretores, fotógrafos, médicos, artistas gráficos e produtores. Juntos eles realizam peças de teatro, intervenções no espaço urbano, festivais de música, entre outras ações coletivas. Participando da conversa, foi ele quem melhor explicou como a multiplicidade de formações e o hibridismo dos integrantes pode favorecer a colaboração e o aprendizado.
[...] a gente tá buscando um formato, uma estrutura que dê conta dessa formação transversal, que a gente pudesse dentro do coletivo fazer isso, já que design é só uma pessoa que faz, então cola uma pessoa com ela durante 6 meses para ser aprendiz dela, sabe? Para daqui a 6 meses essa designer poder se liberar dessa função que ela não gosta de fazer, que ela faz por necessidade, e poder assumir uma outra função ali dentro do coletivo que tenha mais afinidade com o desejo dela. [...] A gente pensou em 2 ou 4 graus de participação, não com esses nomes, mas para se entender: a função começaria sendo exercida por um mestre, entre aspas, e um aprendiz; e depois de, sei lá, 6 meses esse aprendiz vira mestre, e esse mestre se torna um consultor; e aí gira, e alguém que tá com outra função como mestre, se torna aprendiz de uma outra função e continua como consultor naquela outra (Bruno).

O depoimento de Bruno sugere que a perícia e a maestria podem ser compartilhadas em grupos heterogêneos. Não se trata, portanto, de abrir mão da sua experiência, mas adicionar a ela outras experiências, multiplicando os saberes. No modelo proposto por Bruno, todos se beneficiam a partir da troca de conhecimentos. Em Juntos, Sennett (2012a) buscou mostrar como esse intercâmbio é vital para sociedade. Os depoimentos ilustram a importância e os desafios da prática colaborativa em seus espaços profissionais.

\section{Colaboração enquanto habilidade}

Sennett (2012a) defende que a habilidade de cooperar é fundamental para a prosperidade da sociedade, e que embora esteja em nossos genes, ela precisa ser exercitada. Diz o autor no prefácio:

A cooperação azeita a máquina de concretização das coisas, e a partilha é capaz de compensar aquilo que acaso nos falte individualmente. A cooperação está embutida em nossos genes, mas não pode funcionar presa a comportamentos rotineiros; precisa desenvolver-se e ser aprofundada (SENNETT, 2012a, p. 9).

Nos depoimentos, colaboração apareceu como um conceito central nas dinâmicas de trabalho. Todos, em menor ou maior grau, disseram depender ou desejar a ajuda de outros na realização dos seus trabalhos. A cooperação pode ocorrer de forma espontânea, pode ser solicitada ou até mesmo imposta, dependendo da estrutura da empresa. Nesse aspecto, o clima organizacional, o nível de afeto entre os pares e as divisões hierárquicas são determinantes para a efetuação de uma prática colaborativa. Nos depoimentos, encontramos diferentes tipos de relações de cooperação.

Eliza é coordenadora de projetos numa fundação de educação e cultura. Atualmente ela é responsável por um projeto de habilitação profissional de jovens, que combina recursos de educação à distância e presencial. Ao descrever suas atividades diárias, Eliza cita uma equipe de 15 pessoas que precisa trabalhar em colaboração para o projeto ser concebido, efetuado e mantido. " $E$ muita gente envolvida. Equipe, consultores, pessoas que 
pesquisam e vêem demanda social, pessoas que pensam melhores metodologias para resolver uma determinada questão, é todo mundo" (Eliza).

Para Eliza o trabalho em colaboração é uma marca distintiva da sua empresa. O depoimento de Silvana, gerente de projetos na mesma fundação, corrobora a afirmação de Eliza.

Geralmente eu tenho muita coisa para fazer e eu dependo muito de outras pessoas para resolver, para dar ok em um cronograma, (dependo) tanto de equipe interna da fundação, como de fornecedores e parceiros, e como eu tô numa posição de gerenciamento de projetos, $80 \%$ do meu tempo é me comunicando com parceiros, com áreas "meio" da fundação, seja um jurídico, comunicação ou outra área, é pessoal da minha equipe e fornecedores, então $80 \%$ do meu tempo é me comunicando com as pessoas, eu preciso dessas pessoas para realizar o meu trabalho, para o meu trabalho, colaboração é fundamental (Silvana).

Em seus depoimentos, fica claro o papel de colaboração como uma forma de suprir capacidades que nos faltam. De forma sucinta, Sennett define cooperação como uma troca em que as partes se beneficiam. O autor destaca que todos os animais sociais, aí incluindo os seres humanos, agem em apoio recíproco, no sentido de conseguir em conjunto o que não são capazes de alcançar sozinhos (SENNETT, 2012a, p. 15). No entanto, a forma de se organizar varia de acordo com o ambiente.

[...] colaboração é assim: eu tenho uma idéia ou eu tenho um problema, ele é posto na mesa para 30 pessoas resolverem; então a gente trabalha em cima disso, fazemos reunião em cima disso, então colaboração é realmente complementar uma idéia e construir a melhor solução (Eliza).

As empresas têm papel fundamental no desenvolvimento dessa habilidade. Como dito anteriormente, a estrutura das empresas foi fator decisivo para a experiência de colaboração narrada nas conversas. Eliza e Silvana acreditam que têm facilidade em colaborar e encontrar colaboração porque a empresa favorece essa prática e o encontro;

[...] vejo que é o modo de fazer da fundação. Para dar uma idéia, existe uma ação do próprio recursos humanos (RH), da própria estrutura da empresa, tem núcleos de inovação, núcleos de troca, tem reuniões de várias equipes, de várias pessoas de equipes que fundam essa conversa para solucionar problemas diversos, por exemplo, tem um grupo que a gente chama de grupo de inovação e comunicação e um dos desafios foi criar uma solução para divulgar o museu da fundação, então tá todo mundo colaborando, não é o projeto do fulano, fulano é de outro projeto, mas ele tá colaborando nisso. Eu acho isso muito legal na fundação. Essa cultura da colaboração existe. [...] Eu acho que especificamente, na área que a gente tem hoje existe um senso de colaboração muito grande, as pessoas se envolvem, mesmo que não seja responsabilidade delas, projeto delas (Eliza).

Sennett utiliza a analogia da oficina para explicar como as dinâmicas de colaboração podem ser desenvolvidas e estimuladas nos espaços de trabalho. Traçando um paralelo entre as atividades manuais, o autor sugere que existe um ritmo para o desenvolvimento de qualquer aptidão humana, sendo o primeiro passo a "impregnação do hábito" (SENNETT, 2012a, p. 242). $\mathrm{O}$ autor explica que na oficina, depois de adquirido, o hábito é revisto, aperfeiçoado até tornar-se um ritual. A hipótese de Sennett é que esse mesmo movimento é feito no desenvolvimento de relações colaborativas. $\mathrm{Na}$ experiência de Eliza, a empresa, ao promover espaço de encontros e estimular relações dialógicas favorece o desenvolvimento do hábito da colaboração. No entanto, Sennett reconhece que esse ritual mesmo que estabelecido, não é inabalável. Saber trabalhar com as resistências é fundamental para que o hábito se perpetue. $\mathrm{Na}$ oficina, a resistência pode ser física, como a dificuldade de lidar com determinado material ou insuficiência de ferramentas. Nas relações sociais, a resistência pode ser representada por dificuldades de comunicação, ambiente hostil, competitividade acirrada.

Marcelo experimenta a competitividade como resistência na empresa de assessoria de comunicação onde trabalha. Ele explica como a divisão da empresa em núcleos de atendimento prejudica a execução do seu trabalho.

[...] eu acho que é um problema da empresa, da estrutura da empresa, que por ter núcleos de atendimento, porque tem diversos diretores e esses diversos diretores dividem os clientes da empresa então, tem gente que atende a área de hotelaria, outra que só atende a área de energia, óleo e gás, outras atendem a parte de bancos, área financeira, e a coisa funciona meio que de uma maneira um pouco egoísta, eu acho, de não compreenderem o cliente como um cliente da empresa, eles falam que o cliente é do fulano, do diretor tal, então existe um certo conflito de egos de não deixar que um outro núcleo chegue, por exemplo, de não deixar o design atender o cliente, porque aquele diretor tem medo de perder aquele cliente para outro núcleo, então eles incentivam uma competição interna, uma competitividade que eu acho burra (Marcelo).

$\mathrm{Na}$ fala de Marcelo é possível perceber como a competição aparece como empecilho para o trabalho colaborativo. Embora reconheça que a colaboração é imprescindível para o trabalho do departamento de design, Marcelo destaca as dificuldades que a rivalidade entre os conceitos pode gerar.

Para o design não existe trabalhar sem colaboração, entendeu? Tem que ter. Eu acho que a empresa quer até vender isso, mas acho que a própria estrutura, de diretorias divididas que brigam entre si, quem lucra mais, quem tem mais cliente, acho que a forma que tá dividido isso lá dentro aumenta a competitividade, quer dizer, eles falam muito de colaboração, mas acaba (essa estrutura) favorecendo a competitividade (Marcelo).

Sennett fala de duas estratégias comumente implementadas pelas empresas para obter resultados de qualidade: incentivo à concorrência e o estímulo ao coletivismo. A primeira aposta que a competição individual tem mais chances de gerar bons trabalhos, enquanto a segunda espera que o trabalho em colaboração dê bons frutos. Embora Sennett seja um entusiasta do segundo modelo, ele observa que a estratégia não está livre de percalços. O que freqüentemente ocorre, é uma 
política pouco clara que busca unir ambas estratégias.O autor observa que quando a cooperação é imposta pela empresa, corre o risco de tornar-se mera performance.

Em princípio, muitas empresas adotam as doutrinas do trabalho em equipe e da cooperação, esses princípios são freqüentemente uma farsa. Constatamos que as pessoas davam demonstração de comportamento amistoso e cooperativo sob o olhar controlador dos executores da vontade do patrão (SENNETT, 2009, p. 45).

A experiência de Laura é ilustrativa da dicotomia competição/cooperação. Na empresa de consultoria em que trabalha a forma de avaliação entre pares faz com que os colegas de mesmo nível hierárquico se avaliem (o resultado da avaliação reflete na bonificação). Para Laura esse processo prejudica a confiabilidade da própria avaliação além de estimular uma competição.

[...] existe um sistema de avaliação que faz com que os pares, indiretamente estão sempre competindo, porque no final você vai ser avaliado com o seu par, e se você for melhor que ele você ganha mais dinheiro (participação de lucros) então sempre existe uma competição entre os pares e ainda tem que existir um espirito de colaboração que nem sempre existe, é mais dito que praticado [...] a empresa tem essa coisa de um ambiente colaborativo, de que a gente tem que trocar e nem sempre é assim, o mundo corporativo é meio assim, né, um querendo puxar o tapete do outro, você tem que se proteger um pouco, eu acho [...] Eu sinto isso no geral, sabe? Poderia ser mais colaborativo, acho que a competição ainda é muito acirrada (Laura).

Sennett argumenta que recompensas individuais, como bonificações e promoções, podem com frequência enfraquecer laços de confiança e levar ao entesouramento de informações. Nesse sentido, ao invés de estimular a colaboração, esse modelo de avaliação acirra a competição. Entretanto, o autor argumenta que a competição não precisa necessariamente interpor-se no caminho da colaboração; segundo Sennett, existe uma íntima relação entre os dois conceitos. É preciso, contudo, encontrar o equilíbrio. Ele recorre a exemplos do reino animal para amparar sua tese. Os macacos, as abelhas e os seres humanos são animais sociais que cooperam naturalmente pelo simples fato de não poderem sobreviver sozinhos. Assim, dividir trabalho e se organizar em equipes são formas de multiplicar nossos poderes insuficientes. No entanto, essa relação é instável e está constantemente sujeita a desequilíbrios. As trocas e os rituais são formas de organizar essa relação.

Quem quer que tenha praticado esportes em equipe, fechado um negócio ou criado filhos sabe que a cooperação mútua e a competição podem combinar. A contracorrente da competição é agressão e raiva, sentimentos profundamente enraizados nos seres humanos. Ensaios, conversas, coalizões, comunidades e oficinas podem contrabalançar esse impulso destrutivo, pois o impulso da boa vontade também está gravado em nossos genes. Como animais sociais, precisamos descobrir pela experiência como encontrar o equilíbrio (SENNETT, 2012a, p. 85).

Fractal, Rev. Psicol., v. 29 - n. 1, p. 54-64, 2017
Para ilustrar, Sennett divide as trocas e os rituais em categorias, no entanto, o recurso de tomar o reino animal como exemplo dificulta um pouco a compreensão do que o autor quer dizer e, sobretudo, como traçar paralelos com a vida prática. De modo geral, Sennett nos deixa entender que o equilíbrio entre competição e cooperação não acontece naturalmente, sem vontade ou esforço das partes envolvidas. Para que a competitividade não anule os benefícios da colaboração é preciso desenvolver habilidades de negociação.

Frente a um colega que não estava disposto a cooperar, Cecília se viu tendo que desenvolver sua capacidade de negociação. Ela explica que ainda que não exista uma cultura estabelecida na empresa, a criação colaborativa acabou se configurando como uma prática. No entanto, ela ressalta que não é o perfil de todo mundo.

[...] eu tenho uma tendência a precisar de diálogo para desenvolver as coisas, eu não trabalho muito sozinha, eu naturalmente preciso de diálogo então, enfim, eu conto com a colaboração de todo mundo de alguma forma; não é o perfil de todo mundo. A gente está com um caso agora na empresa de um cara que não tem um perfil colaborativo, ele vem de uma empresa muito babaca e ele está tendo dificuldade de se adaptar, sabe, de dialogar com as pessoas, porque ele não tem essa experiência (Cecília).

O medo ou recusa de se abrir a dinâmicas de troca é contemplado por Sennett; baseando suas reflexões em estudos do pós-guerra, o autor destaca que a ansiedade em gerir formas complexas e exigentes de envolvimento social pode levar os sujeitos a retirar-se. "Essa pessoa transforma-se em um 'eu que não coopera"' (SENNETT, 2012a, p. 219). O autor acredita que a sociedade moderna está gerando um novo tipo de caráter; empenhado em reduzir ansiedades e angústias neutralizando toda a diferença. A aversão social ao diverso inviabiliza o comportamento cooperativo. Na parte final de Juntos, Sennett (2012a) sugere práticas que possam fortalecer a cooperação nos espaços onde ela é escassa; nesse sentido, o autor retoma as reflexões iniciadas em $O$ artifice (SENNETT, 2009), acerca das habilidades sociais necessárias para condução da vida cotidiana. Conforme já mencionado, oficina, enquanto ambiente de trabalho físico, pode favorecer um comportamento social dialógico. Nesse espaço, pessoas com diferentes qualidades e habilidades, que concordam, mas também divergem, trabalham juntas para construir, refletir e solucionar problemas comuns. Para o autor, esse é o desafio das modernas estruturas de trabalho.

\section{Conclusão}

É evidente o esforço de Richard Sennett em buscar soluções para os problemas que foram, durante as últimas décadas, alvos de crítica do autor. Na virada da década de 1990, motivado pelo apogeu do modelo neoliberal, Sennett se ocupou em denunciar os perigos do que nomeou "novo capitalismo". Nesse período, o autor escreveu uma série de ensaios críticos ao capitalismo, expondo sua visão negativa em relação às conseqüências da lógica capitalista nos diferentes aspectos da vida humana. A 
hipótese defendida pelo autor nesses trabalhos é de que as novas formas de organização do trabalho são nocivas ao caráter humano. Pesquisas realizadas com trabalhadores industriais, prestadores de serviço de tecnologia e classe operária de grandes cidades como Boston e Chicago, servem de ilustração para o cenário que o autor descreve. A transição de um capitalismo industrial militarizado para um novo capitalismo global, que Sennett chamou de "novo capitalismo", deixou vários trabalhadores desestruturados nas esferas objetivas - desempregados, precarizados mas, sobretudo no âmbito das suas subjetividades.

Em seu trabalho recente, Sennett buscou refletir sobre valores e práticas que possam fortalecer os laços sociais dissolvidos pela nova economia e estimular o trabalho de qualidade, enfraquecido pelas pressões do tempo e a fragmentação das estruturas. Homo faber não abre mão das críticas que constituíram os trabalhos anteriores do autor, mas diversamente, busca na história, na filosofia e até mesmo na biologia, exemplo de como os animais sociais são capazes de driblar adversidades através do trabalho bem feito e coletivo.

Este artigo buscou estabelecer um diálogo entre a bibliografia do sociólogo Richard Sennett e as experiências narradas de jovens profissionais de diferentes esferas produtivas. Os depoimentos trouxeram à tona questões amplamente discutidas por Sennett ao longo de quatro décadas de produção intelectual. Os conceitos de flexibilidade, perícia e colaboração foram privilegiados nessa discussão.

$\mathrm{Na}$ fala dos entrevistados, flexibilidade apareceu como um conceito intimamente ligado à idéia de autonomia e liberdade, e desejado em oposição a estruturas rígidas de trabalho. No entanto, assim como ressalta o autor, houve falas em que flexibilidade foi associada à idéia de desamparo e precarização. Do mesmo modo, a relação com o tempo do novo capitalismo e as conseqüências para a formação especializada foram problematizadas nos depoimentos. Sennett argumenta que a cultura a curto prazo das modernas estruturas de trabalho está enfraquecendo a noção de carreira, levando a uma desvalorização da perícia na formação e nas práticas profissionais. Embora algumas experiências corroborem a hipótese do autor, o aspecto do tempo e a diversidade das capacitações apareceram como um aspecto paradigmático do nosso tempo, nesse sentido, houve discursos que destacavam vantagens de capacitações híbridas e funções polivalentes. Os depoimentos evidenciaram também a centralidade do conceito de colaboração nas dinâmicas de trabalho. Todos os jovens entrevistados, em menor ou maior grau, disseram depender ou desejar a ajuda de outros na realização dos seus trabalhos. A cooperação pode ocorrer de forma espontânea, pode ser solicitada ou até mesmo imposta, dependendo da estrutura da empresa. Nesse aspecto, o clima organizacional, o nível de afeto entre os pares e divisões hierárquicas são determinantes para a efetuação de uma prática colaborativa.

Os depoimentos trouxeram duas grandes contribuições para a reflexão sobre o tema: evidenciaram como a estrutura da empresa molda práticas profissionais individuais e demonstraram as diferentes compreensões dos conceitos em contextos laborais distintos. Nesse sentido, esses conceitos não podem ser interpretados a priori, uma vez que seus significados e valores são construídos no ambiente das organizações.

\section{Referências}

ARENDT, H. A condição humana. Rio de Janeiro: Forense Universitária, 1958

FOUCAULT, M. A ordem do discurso. São Paulo: Loyola, 1996.

SENNETT, R. A corrosão caráter: conseqüências pessoais do trabalho no novo capitalismo. Rio de Janeiro: Record, 1999.

SENNETT, R. Respeito: a formação do caráter em um mundo desigual. Rio de Janeiro: Record, 2004.

SENNETT, R. A cultura do novo capitalismo. Rio de Janeiro: Record, 2006.

SENNETT, R. O artifice. Rio de Janeiro: Record, 2009.

SENNETT, R. Juntos: os rituais, os prazeres e a política da cooperação. Rio de Janeiro: Record, 2012a.

SENNETT, R. Juntos agora. Valor, seção Cultura \& Estilo, Rio de Janeiro. Entrevista concedida a Giovanna Bartucci, 2012b. Disponível em: <http://www.valor.com.br/cultura/2801450/ juntos-agora>. Acesso em: 7 jun. 2013.

SENNETT, R; COBB, J. The hidden injuries of class. New York: Norton, 1972.

Recebido em: 17 de março de 2015

Aceito em: 13 de setembro de 2016 